\title{
PERAN RUANG KOMUNAL DALAM MENCIPTAKAN SENSE OF COMMUNITY STUDI KOMPARASI PERUMAHAN TERENCANA DAN PERUMAHAN TIDAK TERENCANA
}

\author{
Stirena Rossy Tamariska ${ }^{1}$, A. Dwi Eva Lestari ${ }^{2}$, Elisabet Nungky Septania ${ }^{3}$, M. Shoful \\ Ulum $^{4}$ \\ ${ }^{1,2,3,4}$ Program Studi Arsitektur, JTIK, Institut Teknologi Sumatera \\ Jl Terusan Ryacudu, Way Hui, Jati Agung, Lampung \\ *Email: stirena.tamariska@ar.itera.ac.id.
}

\begin{abstract}
ABSTRAK
Sense of community merupakan penentu signifikan kualitas hidup secara umum dan kepuasan dalam kesejahteraan. Dalam kehidupan bermukim, anggotanya harus memiliki sense of community agar komunitasnya tetap bertahan dan hubungan yang berjalan semakin kuat. Adanya hubungan yang kuat antar warga permukiman merupakan salah satu ukuran kepuasan hidup di daerah perumahan. Aktivitas interaksi sosial yang terjadi di ruang komunal menjadi salah satu indikator terhadap sense of community. Ruang komunal di dalam kota keberadaannya bisa direncanakan, bisa pula muncul secara organic (tidak terencana). Masingmasing ruang komunal baik yang 'by design' ataupun 'non design' memiliki peran masing-masing berdasarkan aktivitas dan keseharian yang terjadi. Keberadaan interaksi sosial melalui terbentuknya kelompok pengguna ruang, intensifnya penggunaan ruang dan adanya aktivitas yang beragam dapat menjelaskan bagaimana ruang komunal bermakna bagi masyarakat. Ruang komunal dalam mempertahankan eksistensinya dipengaruhi oleh bagaimana penghuni atau pengguna (user) memanfaatkan ruang komunal tersebut. Kebutuhan ruang komunal dilakukan berdasarkan sebuah kesadaran bahwa interaksi sosial merupakan bagian dari kebutuhan keseharian. Pada ruang komunal kampung kota, interaksi sosial bisa dilakukan kapan saja setiap saat, dengan memanfaatkan ruang-ruang yang justru tidak direncanakan atau ruang yang berada relatif dekat dengan hunian. Ruang komunal baik terencana maupun tidak terencana masing-masing memiliki peran sosial. Sense of community dapat dinilai dari kualitas penggunaan lahan, kualitas fisik ruang komunal dan kualitas sosial. Masing-masing ruang komunal memiliki peran dalam menciptakan sense of community karena faktor lingkungan sangat penting untuk pengembangan rasa kebersamaan dalam komunitas perkotaan. Studi ini dapat digunakan sebagai rekomendasi dalam pembuatan kebijakan untuk untuk memperhatikan hadirnya ruangruang interaksi/ ruang komunal dalam perencanaan permukiman/ perkotaan yang menciptakan Sense of Community.
\end{abstract}

Keywords: Aktivitas Sosial, Ruang Interaksi, Ruang Komunal, Sense of Community, Sosial.

\section{PENDAHULUAN}

Dalam kehidupan bermasyarakat, manusia perlu berinteraksi di lingkungan mereka berada demi terjadinya suatu kerja sama. Interaksi sosial yang terjadi ini merupakan budaya, karena di dalamnya terdapat proses berbahasa. Masyarakat menggunakan bahasa lokal tertentu dan melakukan perkumpulan secara formal maupun informal. Namun saat ini budaya interaksi sosial yang erat antar masyarakat mulai luntur. Pola interaksi berubah akibat hadirnya gadget pada kebanyakan masyarakat golongan menengah ke atas. Nilainilai kebersamaan semakin hilang akibat ketergantungan manusia terhadap teknologi yang demikian tinggi.

Interaksi sosial dapat diartikan sebagai hubungan-hubungan sosial yang dinamis. Walgito (2003) menyatakan bahwa interaksi 
sosial adalah hubungan antara individu satu dengan individu yang lain. Individu satu dapat mempengaruhi individu yang lain atau sebaliknya, sehingga terdapat hubungan yang saling timbal balik. Keberadaan ruang komunal menjadi suatu kebutuhan bagi masyarakat untuk berinteraksi. Menurut Darmiwati (2000), fungsi ruang komunal adalah sebagai wadah interaksi sosial, yang menampung kebutuhan akan tempat untuk bertemu, berinteraksi, melakukan aktivitas bersama.

Dalam interaksi manusia dengan lingkungan, manusia akan berusaha untuk memperoleh keselarasan dengan lingkungannya. Hal ini dimungkinkan karena adanya kemampuan kognitif untuk mengadakan reaksireaksi tertentu terhadap lingkungan yang dapat memenuhi kebutuhannya. Menurut Lang (1987), ruang komunal memberikan kesempatan kepada user untuk bertemu, tetapi untuk menjadikan hal itu diperlukan katalisator. Katalisator merupakan individu ataupun kelompok yang membawa orang secara bersama-sama dalam sebuah aktivitas, diskusi atau topik umum. Menurut Shirvani (1985), ruang komunal adalah ruang tempat untuk berkumpul, bersosialisasi, tempat bermain anak, dan tempat untuk melakukan aktivitas-aktivitas publik lainnya. Faktor sosial merupakan syarat utama menghidupkan ruang komunal, di mana terdapat orang berkumpul dan terjadi interaksi. Selain sosial juga terdapat faktor lingkungan, di mana lingkungan yang nyaman mampu menjadi daya tarik bagi orang untuk datang.

Sense of community adalah hubungan interaksi sosial yang menghasilkan interaksi, hubungan erat, rasa memiliki dan membutuhkan komitmen (McMillan \& George, 1986). Salah satu elemen pembentuk sense of community adalah hadirnya ruang public. Ruang public baik lapangan maupun jalan/ tempat-tempat berkumpul di lingkungan dapat menyediakan ruang pertemuan spontan, yang berfungsi untuk memperkuat ikatan komunitas dan sebagai tempat komunikasi dimana dapat memunculkan ujud Sense of Community.

Studi ini menyelidiki peran ruang publik berupa ruang komunal di perumahan terencana dan tidak terencana dari aktifitas pengguna ruang komunal, dikaitkan dengan Sense of Community. Penting bagi planner dan arsitek ke depan untuk memperhatikan hadirnya ruangruang interaksi yang menciptakan sense of community. Peran ruang-ruang interaksi perlu dikaji ulang dalam perencanaan perumahan/ perkotaan, agar dapat menjadi sarana untuk mempertahankan kearifan budaya lokal, yaitu budaya berinteraksi sosial dan saling mengenal dengan baik antar tetangga. Studi ini dapat digunakan sebagai rekomendasi dalam pembuatan kebijakan untuk untuk memperhatikan hadirnya ruang-ruang interaksi/ ruang komunal dalam perencanaan permukiman/ perkotaan yang menciptakan Sense of Community. Aspek-aspek simbolis yang muncul sebagai representasi ruang interaksi dari masyarakat, dapat menjadi pertimbangan dalam menghadirkan solusi bagi pembangunan skala kota.

\section{Ruang Komunal}

Ruang komunal adalah sebuah setting yang dipengaruhi oleh tiga unsur selain unsur fisiknya yaitu manusia sebagai pelaku, kegiatan dan pikiran manusia (Purwanto, 2007). Berdasarkan pengertian tersebut maka seting tidak dapat dipahami secara utuh tanpa keterkaitan ketiga unsur-unsur tersebut. Menurut Wellman dan Leighton (1979), ruang komunal merupakan kebutuhan ruang yang berfungsi sebagai ruang sosial, yaitu sebagai salah satu kebutuhan pokok pemukim untuk mengembangkan kehidupan bermasyarakat. Menurut Newman (1990), ruang komunal dapat membangkitkan hasrat penghuni menjadi satu komunitas, sehingga dapat dikondisikan sifat pemakaian, pemeliharaan dan pengawasan secara bersama.

\section{Peranan Ruang Komunal}

Carmona et al (2003:124) dan Parkinson (2012:51) menguraikan bahwa satu aspek penting dalam ruang publik yang demokratis adalah tersedianya aksesibilitas yang baik. Dengan aksesibilitas yang baik, akan mendorong pemanfaatan ruang publik oleh pengguna yang beragam. Keberagaman pengguna ini dapat diukur dari keberagaman gender, usia dan beberapa karakteristik lainnya. Pada akhirnya, keberadaan interaksi sosial melalui terbentuknya kelompok pengguna ruang, intensifnya penggunaan ruang dan adanya aktivitas yang beragam dapat menjelaskan bagaimana ruang publik bermakna bagi masyarakat.

Pria, wanita anak-anak dan orang tua memiliki persepsi yang berbeda terhadap ruang publik yang dapat mempengaruhi penggunaan ruang publik sehingga berbagai kegiatan dan keragaman dalam usia dan jenis kelamin mampu 
menunjukkan seberapa responsif ruang tersebut bagi pengguna dengan tujuannya (Mehta, 2007). Peranan komunal dapat ditelaah lebih lanjut berdasarkan teori peranan Ruang Publik yang dinyatakan oleh Carmona, et al (2008), yaitu:

a. Ekonomi:

- Memberi nilai yang positif pada nilai properti

- Mendorong performa ekonomi regional

- Dapat menjadi bisnis yang baik

b. Kesehatan:

- Mendorong masyarakat untuk aktif melakukan gerakan fisik

- Menyediakan ruang informasi dan formal bagi kegiatan olahraga

- Mengurangi stres

c. Sosial:

- Menyediakan ruang bagi interaksi dan pembelajaran sosial pada segala usia

- Mengurangi resiko terjadinya kejahatan dan sikap anti-sosial

- Mendorong dan meningkatkan kehidupan berkomunitas

- Mendorong terjadinya interaksi antarbudaya

Dalam kaitannya dengan pelaksanaan aktivitas sosial, Mehta (2007) mempergunakan beberapa variabel yang dipergunakan untuk mengukur dan menyusun "Good Public Space Index", antara lain:

a. Intensitas penggunaan, yang diukur dari jumlah orang yang terlibat dalam aktivitas statis dan dinamis pada ruang publik.

b. Intensitas aktivitas sosial, yang diukur berdasar-kan jumlah orang dalam setiap kelompok yang terlibat dalam aktivitas statis dan dinamis pada ruang publik.

c. Durasi aktivitas, yang diukur berdasarkan berapa lama waktu yang dipergunakan orang untuk beraktivitas pada ruang publik.

d. Variasi penggunaan, yang diukur berdasarkan keberagaman atau jumlah tipologi aktivitas yang dilaksanakan pada ruang publik.

e. Keberagaman pengguna, yang diukur berdasarkan variasi pengguna berdasarkan usia, jenis kelamin dan lain sebagainya.

\section{Pengertian Sense of Community}

Dalam sebuah komunitas, sense of community merupakan bagian yang berperan penting, setiap anggotanya harus memiliki sense of community agar komunitasnya tetap bertahan dan hubungan yang berjalan semakin kuat. Sense of community adalah hubungan interaksi sosial yang menghasilkan rasa memiliki di dalam kelompok dan membutuhkan komitmen (McMillan \& Chavis, 1986). Dalam konteks lingkungan, hubungan antar warga memberikan kepuasan hidup di daerah perumahan (Blanchard, 2008; Fried, 1984), dan juga merupakan penentu signifikan kualitas hidup secara umum dan kepuasan dalam kesejahteraan (Rogers \& Sukolratanametee, 2009). Hal ini menyiratkan bahwa area fisik dalam berbagai ukuran dan bentuk dapat membuat penghuni merasa terhubung secara sosial (Talen, 1999).

Sense of community adalah aspek penting dalam lingkungan untuk meningkatkan perasaan aman dan menghilangkan peluang untuk kejahatan (Austin, Furr, \& Spine, 2002). Namun, dalam hal desain lingkungan, itu akan mempengaruhi hubungan antara komunitas, terutama di lingkungan fisik. Talen (1999) berpendapat bahwa faktor lingkungan adalah salah satu faktor yang mempengaruhi dan merangsang hubungan masyarakat. Uzzell, Pol dan Badenas (2002), menemukan bahwa elemen lingkungan fisik dan sosial dapat meningkatkan hubungan di antara penghuni yang menggunakan ruang komunitas di dua lingkungan Guildford, Surrey, Inggris. Studi ini menemukan bahwa $70 \%$ responden menyebutkan bahwa lingkungan Onslow lebih baik dalam hal citra fisik dibandingkan dengan lingkungan Stoughton (Uzzell et al. 2002).

\section{Ruang Komunal dan Sense of Community \\ Dalam lingkungan fisik, lima elemen} diyakini dapat meningkatkan hubungan masyarakat, yaitu arsitektur dan desain tapak, kepadatan dan skala, jalan, ruang publik, dan penggunaan lahan campuran (Talen, 1999). Ruang publik menyediakan tempat untuk pertemuan spontan, yang berfungsi untuk memperkuat ikatan komunitas. Tempat-tempat berkumpul di lingkungan memberikan ruang kepada masyarakat sebagai tempat komunikasi. 
Berikut adalah gambaran hubungan antara ruang komunal dan sense of community (Gambar 1):

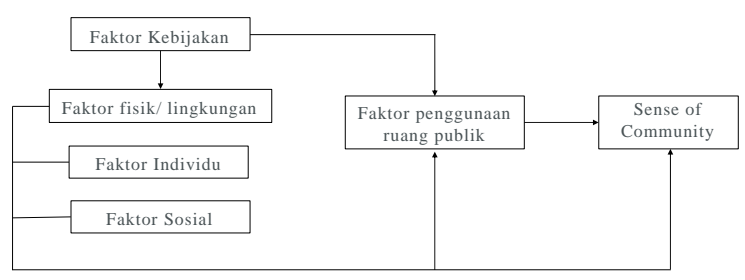

Gambar 1. Hubungan antara ruang publik dan sense of community (Source: Francis et al., 2012).

Menurut psikolog komunitas Plas dan Lewis, faktor lingkungan sangat penting untuk pengembangan rasa kebersamaan dalam komunitas perkotaan (Plas \& Lewis, 1996). Cochran juga berpendapat bahwa perencana mampu melestarikan dan memperkuat rasa kebersamaan masyarakat melalui kedua kebijakan sosial dan strategi desain fisik (Cochran, 1994). Oleh karena itu, dapat disimpulkan bahwa lingkungan binaan mampu memengaruhi sense of community masyarakat baik secara langsung maupun tidak langsung melalui peningkatan peluang interaksi di antara penduduk (Francis et al., 2012). Jalan-jalan komersial di lingkungan perumahan bertindak mirip dengan jalan utama untuk sebuah kota. Jalan komersial atau pusat lingkungan adalah jalan untuk interaksi dan komunikasi. Warga dapat memenuhi kebutuhan sehari-hari mereka melalui jalan-jalan komersial dan menjadi pengunjung tetap sambil bersosialisasi dengan warga lain. Sebuah studi oleh Mehta menunjukkan bahwa jalan komersial di lingkungan dapat mempengaruhi kualitas sosial, penggunaan lahan dan fisik (Mehta, 2007; Mehta, 2013). Kualitas penggunaan lahan diantaranya terkait dengan variasi bisnis, keberadaan warung, ataupun toko. Kualitas fisik diantaranya termasuk tempat duduk komersial dan publik, lebar trotoar, naungan dan artikulasi bangunan.

\section{METODE PENELITIAN}

Penelitian ini bersifat eksperimental dan kualitatif, mengkaji lebih dalam peran ruang komunal di perumahan tidak terencana (kampung kota) dan perumahan terencana dalam menciptakan sense of community berdasarkan analisis aktivitas di Ruang Komunal.
Manfaatnya untuk pembangunan atau pengembangan daerah yang memperhatikan keberadaan ruang komunal dengan sense of community bagi perumahan dan permukiman di Indonesia. Metode pengumpulan data primer dilakukan dengan cara pengamatan langsung pada lokasi dengan alat bantu rekam berupa foto, video, rekaman suara dan catatan.

\section{HASIL DAN PEMBAHASAN}

\section{Deskripsi Lokasi Perumahan Terencana \\ Terdapat dua titik ruang komunal di} Perumahan Sukaluyu (Terencana). Ruang komunal pertama (1) bernama Taman Sidoluhur, berada di Jalan Sidoluhur, Cikutra, Bandung, dan yang kedua (2) bernama Taman Pecah Kopi, berada di Jalan Batik Keris, Cikutra, Bandung (Gambar 2 dan 3). Ruang komunal (1) berada di tengah-tengah Perumahan Sukaluyu, sedangkan ruang komunal (2) berada di sudut Perumahan Sukaluyu.

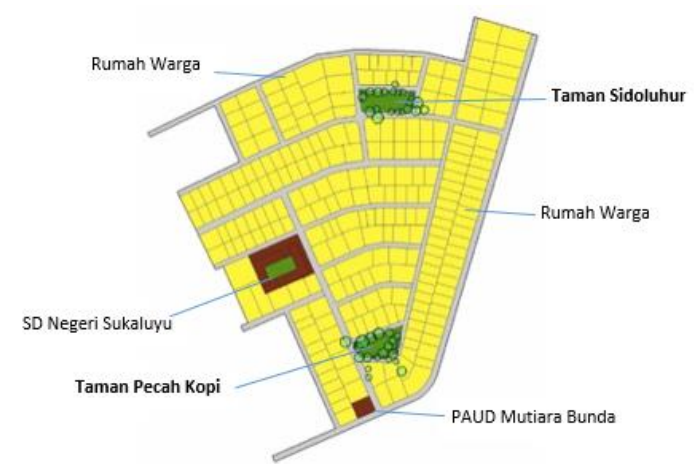

Gambar 2. Keterangan Lokasi Ruang Komunal di Perumahan Terencana

Ruang komunal pertama dan kedua adalah ruang komunal berupa lapangan dengan rumput, yang digunakan untuk berbagai macam kegiatan. Keduanya memiliki tempat sampah sebagai fasilitas penunjang kebersihan. Berdasarkan observasi yang dilakukan, keadaan kedua ruang komunal relatif bersih (tidak terdapat sampah yang berserakan).

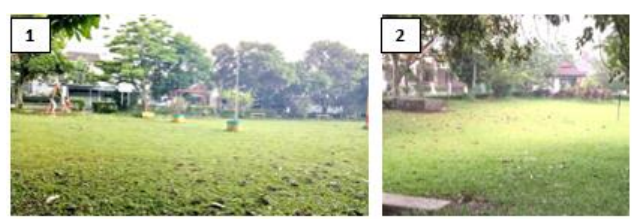


Gambar 3. Situasi Ruang Komunal Perumahan Terencana

\section{Deskripsi Lokasi Perumahan Tidak Terencana}

Objek kajian adalah berupa koridor jalan kampung kota, yaitu Jalan Tubagus Ismail Bawah, RT 05 RW 01, Lebakgede, Coblong, Bandung. Wilayah studi pada koridor jalan ini merupakan lokasi dengan peruntukan wisma atau pemukiman dengan fasilitasnya. Jalan sasaran merupakan salah satu jalan dengan kondisi yang padat bangunan dengan sedikit ruang terbuka berupa koridor jalan (Gambar 4).

Jalan Tubagus Ismail bawah berbatasan langsung dengan Jalan Dipatiukur di bagian barat, Jalan Tubagus Ismail Raya di bagian utara, dan permukiman warga di timur dan selatan. Koridor jalan ini berupa satu lajur jalan RT 05 yang tergabung dalam wilayah RW 01 Kelurahan Lebakgede, Kecamatan Coblong, berdekatan dengan kampus UNIKOM, Bandung.

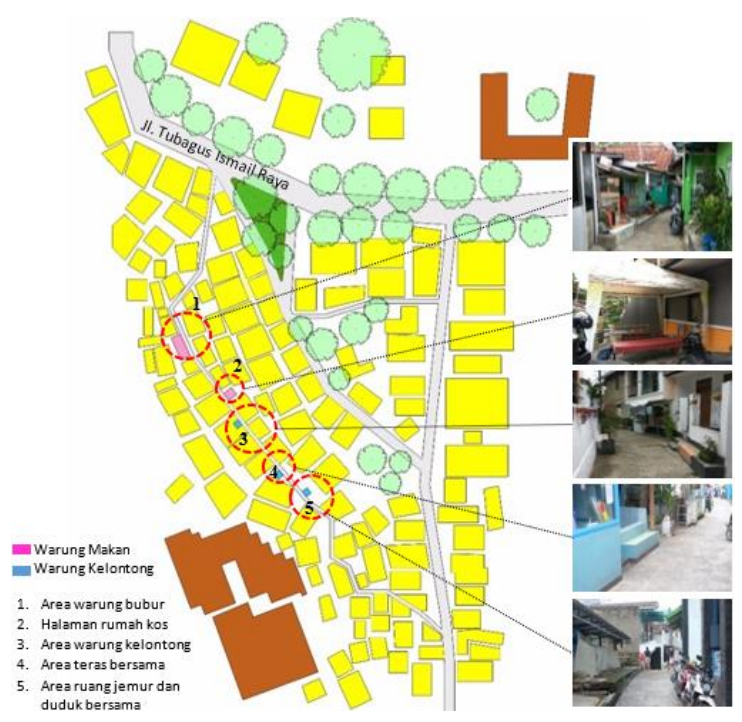

Gambar 4. Lokasi Ruang Komunal Perumahan Tidak Terencana

Ruang Komunal Kampung Tubagus Ismal Bawah berada di koridor jalan sekaligus menjadi ruang sirkulasi masuk dan keluar kampung, sehingga mudah diakses oleh warga setempat. Interaksi sosial paling sering terjadi di warung makan dan warung kelontong sebagai tempat pemenuhan kebutuhan sehingga muncullah ruang komunal yang tidak terencana, di sekitar area warung makan dan warung kelontong. Berdasarkan observasi yang dilakukan, keadaan kelima area ruang komunal relatif bersih (tidak terdapat sampah yang berserakan), walaupun prasarana kebersihan tidak tersedia (Gambar 5).

\section{Aktivitas di Ruang Komunal Perumahan Terencana}

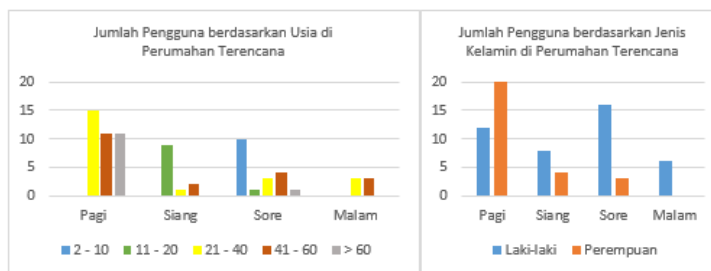

Gambar 5. Jumlah Pengguna Ruang Komunal berdasarkan Usia (kiri) dan Jenis Kelamin (kanan) di Perumahan Sukaluyu (Terencana)

Data di atas diambil berdasarkan pengamatan di waktu yang berbeda yaitu pagi hari pukul $05.00-08.00$, siang hari pukul 11.00-13.00, sore hari pukul 16.00-18.00, dan malam hari pukul 18.00-22.00. Dari data di atas menunjukkan bahwa ruang komunal di Perumahan Sukaluyu pada pagi hari didominasi oleh kelompok usia 21-40, 41-60, dan di atas 60 tahun. Kelompok usia ini sebagian besar merupakan wiraswasta dan pensiunan, sehingga mereka memiliki waktu untuk berolahraga seperti bermain gateball dan senam. Sedangkan, kelompok usia 2-10 dan 11-20 tidak terlihat ada yang menggunakan ruang komunal karena pada umumnya mereka pergi bersekolah. Pada siang hari, terlihat bahwa kelompok usia 11-20 paling banyak menggunakan ruang komunal untuk nongkrong. Keragaman kelompok usia paling terlihat pada sore hari. Hal ini dapat terlihat dari banyaknya kelompok usia 2-10 yang bermain bola, kelompok usia 21-40 dan 41-60 yang menemani anak dan berolahraga, dan pengguna di atas 60 tahun yang menggunakan fasilitas batu refleksi. Pada malam hari, kelompok usia yang beraktivitas hanya kelompok 21-40 dan 41-60 yang merupakan satpam.

\section{Aktivitas di Ruang Komunal Perumahan Tidak Terencana \\ Pada koridor jalan Tubagus Ismail Bawah terdapat lima area yang menjadi titik kumpul}


warga kampung dalam kegiatannya sehari-hari. Aktivitas yang terjadi dalam satu area dapat bervariasi menurut pelaku dan waktunya (Gambar 6).

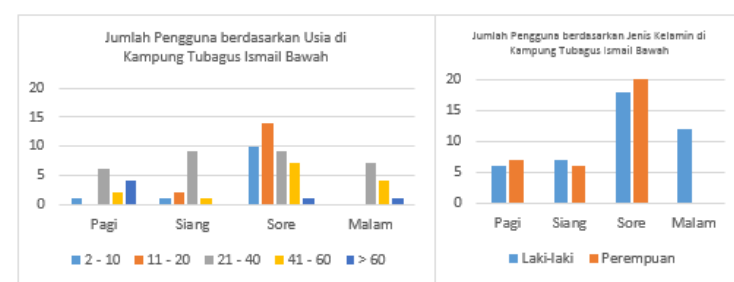

Gambar 6. Jumlah Pengguna Ruang Komunal berdasarkan Usia (kiri) dan Jenis Kelamin (kanan) di Kampung Tubagus Ismail Bawah (Tidak Terencana)

Data di atas diambil berdasarkan pengamatan di waktu yang berbeda yaitu pagi hari pukul $05.00-08.00$, siang hari pukul 11.00-13.00, sore hari pukul 16.00-18.00, dan malam hari pukul 18.00-22.00. Pada Kampung Tubagus Ismail Bawah, kelompok usia 21-40 terlihat paling banyak menggunakan ruang komunal untuk berjualan dan menjaga serta memberi makan anak. Kelompok usia ini juga paling banyak terlihat pada siang hari, di antaranya adalah pedagang dan mahasiswa yang membeli makan siang. Kelompok usia yang beragam juga terlihat pada sore hari di ruang komunal perumahan tidak terencana. Didominasi oleh kelompok usia 11-20, aktivitas yang dilakukan adalah bermain. Pada malam hari, kelompok usia 21-40 mendominasi dengan aktivitas berdagang, mengobrol, dan minum kopi.

\section{Peran Ruang Komunal}

Peran ruang komunal sebagai wadah aktivitas kesehatan, sosial dan ekonomi terlihat di ruang komunal di Perumahan Sukaluyu dan Tubagus Ismail Bawah. Dalam aktivitas ekonomi dan kesehatan terdapat interaksi antar pengguna sehingga aktivitas tersebut juga merupakan aktivitas sosial. Berfokus pada aspek sosial, maka aktivitas yang terjadi digolongkan menjadi tiga pola aktivitas yaitu: sosialkesehatan, sosial-ekonomi dan murni aktivitas sosial. Aktivitas yang termasuk ke dalam sosialekonomi adalah membeli dan menjual makanan serta jajanan. Aktivitas yang termasuk ke dalam sosial-kesehatan adalah lari pagi, bermain gateball, bersepeda, senam, refleksi, dan bermain sepak bola. Sedangkan aktivitas murni sosial yang diamati berupa mengobrol, botram, dan menjaga anak (Gambar 7).

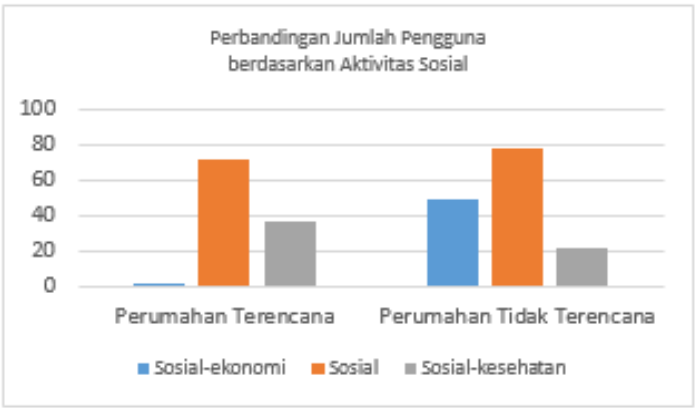

Gambar 7. Perbandingan Jumlah Pengguna berdasarkan Aktivitas Sosial di Perumahan Terencana dan Tidak Terencana

Diagram di atas menunjukkan perbandingan tingkat aktivitas (sosial-ekenomi, sosial, dan sosial-kesehatan) pada ruang komunal di Perumahan Sukaluyu (terencana) dan Kampung Tubagus Ismail Bawah (tidak terencana). Data ini diambil dari hasil pengamatan dari rata-rata jumlah pengguna perharinya. Dari hasil pengamatan dapat dilihat bahwa aktivitas sosial, sosial-ekonomi, dan sosial-kesehatan dapat ditemukan pada kedua jenis perumahan. Perbedaan yang terlihat yaitu di ruang komunal Kampung Tubagus Ismail Bawah, aktivitas sosial-ekonomi lebih tinggi dibandingkan dengan Perumahan Sukaluyu. Sedangkan aktivitas sosial-kesehatan lebih banyak dilakukan di Perumahan Sukaluyu (terencana).

Setelah melihat pola aktivitas sosial yang terjadi di ruang komunal Perumahan Sukaluyu dan Tubagus Ismail Bawah, selanjutnya adalah membandingkan intensitas penggunaan ruang komunal di Perumahan Sukaluyu dan Tubagus Ismail Bawah. Parameter untuk mengidentifikasi pola aktivitas di ruang komunal baik terencana maupun tidak terencana dibagi dalam 4 parameter, yaitu: [a] sifat kegiatan (sosial ekonomi/ sosial/ sosial kesehatan); [b] frekuensi kegiatan (rutin/ tidak rutin); [c] jarak jangkauan (dekat/ jauh); [d] skala kegiatan (intern/ luar). Berdasarkan 4 parameter tersebut, pola aktivitas di ruang komunal dibagi dalam 3 kelompok besar intensitas penggunaan (tinggi/ sedang/ rendah) dapat dilihat pada Tabel 1 dan 2:

Tabel 1. Tingkat Intensitas Penggunaan Ruang Komunal Perumahan Terencana

\begin{tabular}{|c|l|c|c|c|}
\hline \multirow{2}{*}{ No } & Pola Parameter & \multicolumn{3}{|c|}{ Intensitas Penggunaan } \\
\cline { 3 - 5 } & & Tinggi & Sedang & Rendah \\
\hline A & Sifat Kegiatan & & & \\
\hline & Sosial Ekonomi & & & $\sqrt{ }$ \\
\hline
\end{tabular}




\begin{tabular}{|l|l|c|c|c|}
\hline & Sosial & $\sqrt{ }$ & & \\
\hline & Sosial Kesehatan & & $\sqrt{ }$ & \\
\hline B & $\begin{array}{l}\text { Frekuensi } \\
\text { Kegiatan }\end{array}$ & & & \\
\hline & Jam & & $\sqrt{ }$ & \\
\hline & Harian & & $\sqrt{ }$ & \\
\hline & Mingguan & & & $\sqrt{ }$ \\
\hline & Bulanan & & $\sqrt{ }$ & \\
\hline C & Jarak Jangkauan & & & \\
\hline & Dekat & & & $\sqrt{ }$ \\
\hline & Sedang & & $\sqrt{ }$ & \\
\hline & Jauh & & & \\
\hline D & Skala Kegiatan & & & \\
\hline & Intern/ Kelompok & & & $\sqrt{ }$ \\
\hline & Luar Perumahan & $\sqrt{ }$ & & \\
\hline
\end{tabular}

Tabel 2. Tingkat Intensitas Penggunaan Ruang Komunal Perumahan Tidak Terencana

\begin{tabular}{|c|c|c|c|c|}
\hline \multirow[t]{2}{*}{ No } & \multirow[t]{2}{*}{ Pola Parameter } & \multicolumn{3}{|c|}{ Intensitas Penggunaan } \\
\hline & & Tinggi & Sedang & Rendah \\
\hline \multirow[t]{4}{*}{$\mathbf{A}$} & Sifat Kegiatan & & & \\
\hline & Sosial Ekonomi & & $\sqrt{ }$ & \\
\hline & Sosial & $\sqrt{ }$ & & \\
\hline & Sosial Kesehatan & & & $\sqrt{ }$ \\
\hline \multirow[t]{5}{*}{$\mathbf{B}$} & $\begin{array}{l}\text { Frekuensi } \\
\text { Kegiatan }\end{array}$ & & & \\
\hline & Jam & $\sqrt{ }$ & & \\
\hline & Harian & $\sqrt{ }$ & & \\
\hline & Mingguan & & & $\sqrt{ }$ \\
\hline & Bulanan & & & $\sqrt{ }$ \\
\hline \multirow[t]{4}{*}{$\mathbf{C}$} & Jarak Jangkauan & & & \\
\hline & Dekat & $\sqrt{ }$ & & \\
\hline & Sedang & & & $\sqrt{ }$ \\
\hline & Jauh & & & $\sqrt{ }$ \\
\hline \multirow[t]{3}{*}{ D } & Skala Kegiatan & & & \\
\hline & Intern/ Kelompok & $\sqrt{ }$ & & \\
\hline & Luar Perumahan & & & $\sqrt{ }$ \\
\hline
\end{tabular}

Aspek lain yang dilihat yaitu frekuensi kegiatan yang dibagi menjadi skala jam, hari, minggu, dan bulan. Berdasarkan hasil pengamatan dan wawancara, intensitas penggunaan pada Perumahan Tubagus Ismail Bawah lebih tinggi dibanding Perumahan Sukaluyu dalam skala jam dan hari. Hal ini dapat dilihat dari penggunaan ruang pada Perumahan Tubagus Ismail Bawah untuk pemenuhan kebutuhan sehari-hari seperti berjualan, membeli makan, dan menjaga serta memberi makan anak. Ruang ini juga merupakan sirkulasi utama yang sering dilewati oleh penghuni perumahan tersebut.

Dalam skala minggu, ruang komunal pada Perumahan Sukaluyu memiliki intensitas yang lebih tinggi karena adanya kegiatan botram dan senam. Kegiatan botram banyak dilakukan oleh orang tua murid (ibu-ibu) yang bersekolah di SD Negeri Sukaluyu. Sedangkan pada perumahan Tubagus Ismail Bawah tidak ada kegiatan rutin yang dilakukan setiap minggu ataupun bulannya. Dilihat dari aspek jarak jangkauan dan skala kegiatan, pengguna pada Perumahan Sukaluyu sebagian besar berasal dari luar area perumahan. Sedangkan pada Perumahan Tubagus Ismail Bawah, pengguna yang paling banyak menggunakan ruang komunal berasal dari dalam perumahan.

\section{KESIMPULAN}

Ruang komunal baik terencana maupun tidak terencana masing-masing memiliki peran sosial. Peran sosial Ruang Komunal di Perumahan Terencana sebagian besar diakomodasi dari aktivitas kesehatan, sedangkan peran sosial Ruang Komunal Perumahan Tidak Terencana sebagian besar diakomodasi dari aktivitas ekonomi. Adanya aktivitas kesehatan di Ruang Komunal Terencana dan aktivitas ekonomi di Ruang Komunal Tidak Terencana memicu adanya interaksi sosial sehingga peran sosial dari Ruang Komunal dapat dilihat dan dinilai.

Ruang komunal dengan intensitas penggunaan tinggi, dalam mempertahankan eksistensinya dipengaruhi oleh bagaimana penghuni atau pengguna (user) memanfaatkan ruang-ruang tersebut sebagai ruang komunal. Kebutuhan ruang komunal dilakukan berdasarkan sebuah kesadaran bahwa interaksi sosial merupakan bagian dari kebutuhan keseharian tanpa harus dibatasi oleh sekat-sekat formal atau tidak formalnya kegiatan, bisa dilakukan kapan saja setiap saat, dengan memanfaatkan ruang-ruang yang justru tidak direncanakan atau ruang yang berada relatif dekat dengan hunian. Bonner (dalam Gerungan, 1991) mengemukakan bahwa kebutuhan penghuni dari suatu lingkungan permukiman dalam hubungannya dengan kegiatan interaksi sosial adalah terpenuhinya kebutuhan untuk 
melakukan kontak sosial secara individu maupun kelompok. Hal tersebut diperkuat oleh Soekanto (1990), bahwa interaksi sosial adalah kunci dari kehidupan sosial, karena tanpa adanya interaksi tidak mungkin ada kehidupan bersama.

Sense of community dalam kasus ini dilihat dari peran ruang komunal berdasarkan aktivitas dalam ruang komunal. Adanya ruang komunal baik terencana maupun tidak terencana, keduanya berperan penting sebagai sarana atau tempat berinteraksi. Pada Perumahan Terencana, interaksi tercipta sebagian besar melalui kegiatan olahraga rutin, sedangkan pada Perumahan Tidak Terencana interaksi banyak terjadi sebagai rutinitas warga bersosialisasi. Masing-masing ruang komunal memiliki peran dalam menciptakan sense of community karena pada Ruang Komunal baik yang terencana maupun tidak terencana terdapat aktivitas sosial. Aktivitas sosial di Ruang Komunal Perumahan Tidak Terencana memiliki frekuensi kegiatan dalam skala jam dan harian yang tinggi, menandakan bahwa aktivitas sosial telah menjadi bagian dari rutinitas warga.

Seperti yang di jelaskan di atas, penelitian ini berfokus pada peran ruang komunal dalam menciptakan sense of community dengan sample ruang komunal di Perumahan Sukaluyu dan Tubagus Ismail Bawah (Bandung). Kesimpulan yang ditulis pada penelitian ini belum sepenuhnya mewakili ruang komunal yang terdapat di Kota Bandung, namun sebatas menjadi sample atau perwakilan ruang komunal dari jenis Perumahan Terencana dan Tidak Terencana. Penelitian lebih lanjut sebaiknya dilakukan dengan sample yang lebih banyak untuk meneliti peran ruang komunal dalam setting dan karakteristik yang berbeda, seperti luar komunal di luar Kota Bandung atau bahkan ruang komunal yang berada di perumahan yang berkembang di desa-desa. Dengan demikian akan didapatkan sebuah kesimpulan utuh tentang peran ruang komunal dalam menciptakan sense of community.

\section{Daftar Pustaka}

Austin, D. M., Furr, L. A., \& Spine, M. (2002) The Effects of Neighborhood Conditions on Perception of Safety. Journal of Criminal Justice.

Blanchard, A. L. (2008).
Testing a Model of Sense of Virtual Community. Computers in Human Behaviour, 24, 2107-2123.

Carmona M., Magalhaes S., Hammond L (2008) Public space, the management dimension. Routledge, Taylor and Francis Group, London and New York.

Cochran, S. (1994) Defining, understanding, and enhancing sense of community in neighborhoods. Journal of Planning Literature, 9, 92-99

Darmiwati, Ratna (2000) Studi Ruang Bersama dalam Rumah Susun bagi Penghuni Berpenghasilan Rendah. DIMENSI (Jurnal Teknik Arsitektur), 28(2).

Francis, J., Giles-Corti, B., Wood, L., \& Knuiman, M. (2012) Creating sense of community: The role of public space. Journal of Environmental Psychology.

Gerungan, W.A. (1991) Psikologi Sosial. Bandung: Eresco.

James, Paul (2015) URBAN SUSTAINABILITY IN THEORY AND PRACTICE: Circles of sustainability. Chapter 8 page 161. New York: Routlegde.

Lang, Jon (1987) Creating Architectural Theory; The Role of the Behavioural Sciences in Environmental Design. New York: Van Nostrand Reinhold Company.

Mahmoudi Farahani, Leila \& Lozanovska, Mirjana. (2014) A Framework for Exploring the Sense of Community and Social Life in Residential Environments. Archnet-IJAR. 8. 10.26687/archnetijar.v8i3.412.

McKenzie, Stephen (2004) Social Sustainability: Towards Some Definitions. Hawke Research Institute Working Paper Series No. 27, University of South Australia, Australia.

McMillan, D. W., \& Chavis, D. M. (1986) Sense of community: A definition and theory. Journal of community psychology 14(1), 6-23. 
Mehta V (2007) A toolkit for performance measures of public space. 43rd ISOCARP Congress 2007.

Mehta, V. (2013) The street : a quintessential social public space. Abingdon, Oxon; New York, NY: Routledge.

Parkinson, John (2012) Democracy and public space. Oxford University Press.

Plas, J. M., \& Lewis, S. E. (1996) Environmental factors and sense of community in a planned town. American Journal of Community Psychology.

Polese M, Stren R (2000) The Social Sustainability of Cities: Diversity and Management of Change. University of Toronto Press, Toronto, pages 15-16.

Purwanto, E. (2007) Rukun Kota-Kota Berbasis Budaya Guyub. Penelitian Disertasi Jurusan Arsitektur Sekolah Pascasarjana UGM.

Rogers, G. O., \& Sukolratanametee, S. (2009) Neighborhood Design and Sense of Community: Comparing Suburban Neighborhoods in Houstan Texas. Landscape and Urban Planning, 92(2009), 325-334.

Shaftoe, Henry (2008) Convivial urban spaces. Earthscan.

Soekanto, S (1990) Sosiologi Suatu Pengantar. Jakarta: Rajawali Press.

Talen, E. (1999) Sense of community and neighbourhood form: An assessment of the social doctrine of new urbanism. Urban Studies, 36(8), 1361-1379. doi: 10.1080/0042098993033.

Uzzell, D., Pol, E., \& Badenas, D. (2002) Place Identification, Social Cohesion, and Environmental Sustainability. Environment and Behavior, 34(1), 26-53.

Walgito, B (2003) Pengantar Psikologi Umum. Yogyakarta: Andi Offset.
Yiftachel O, Hedgcock D (1993) Urban social sustainability: the planning of an Australian city. Cities 10139 - 157, page 140. 